\title{
Increase Participants Motivation to Learn Students Through Interactive Media on PPKN in SDN Daleman Kidul 1
}

\author{
Slamet Nugroho \\ SDN Daleman Kidul 1 \\ nugrohoslamet7@gmail.com
}

\section{Article History}

accepted $14 / 11 / 2020$

approved $21 / 11 / 2020$

published 26/11/2020

\begin{abstract}
This classroom action research aims to increase the learning motivation of students in following the learning process on PPKn material about the rules in daily life for grade 2 SDN Daleman Kidul 1 in the 2020/2021 academic year through interative PPT media. Motivation to learn is the overall driving force in students that gives rise to learning activities, which ensures the continuity of learning activities, so that the goals desired by learning subjects can be achieved (sardiman, 1986:75). The research conducted was a classroom action research with three cycles, in cycle 1 students who were motivated to learn from 15 students reached $66.67 \%$. In the second cycle there was an increase of $86.67 \%$. As for the third cycle, students who were motivated to learn reached $93.33 \%$. Improvements in learning using interactive PPT media in each cycle have increased in motivating students to learn.
\end{abstract}

Keywords: Interactive media, learning motivation

\begin{abstract}
Abstrak
Penelitian Tindakan kelas ini bertujuan untuk meningkatkan motivasi belajar peserta didik dalam mengikuti proses pebelajaran pada materi PPKn tentang aturan dalam kehidupan sehari-hari kelas 2 SDN Daleman Kidul 1 Tahun pelajaran 2020/2021 melalui media PPT interaktif . = Penelitian yang dilakukuan adalah penelitian tindakan kelas sebanyak tiga siklus,pada siklus 1 peserta didik yang sudah termotivasi belajarnya dari 15 peserta didik mencapai $66,67 \%$. Pada siklus ke II mengalami peningkatan $86,67 \%$. Adapun pada siklus III peserta didik yang sudah termotivasi belajarnya mencapai $93,33 \%$. Perbaikan pembelajaran dengan menggunakan media PPT interakti pada setiap siklusnya mengalami peningkatan dalam memotivasi belajar peserta didikPenelitian Tindakan kelas ini bertujuan untuk meningkatkan motivasi belajar peserta didik dalam mengikuti proses pebelajaran pada materi PPKn tentang aturan dalam kehidupan sehari-hari kelas 2 SDN Daleman Kidul 1 Tahun pelajaran 2020/2021 melalui media PPT interaktif. Penelitian tindakan kelas sebanyak tiga siklus,pada siklus 1 , peserta didik yang sudah termotivasi belajarnya dari 15 peserta didik mencapai 66,67\%. Pada siklus ke II mengalami peningkatan $86,67 \%$. Adapun pada siklus III peserta didik yang sudah termotivasi belajarnya mencapai $93,33 \%$. Perbaikan pembelajaran dengan menggunakan media PPT interakti pada setiap siklusnya mengalami peningkatan dalam memotivasi belajar peserta didik. Kata kunci: Media interaktif, motivasi belajar
\end{abstract}

Social, Humanities, and Education Studies (SHEs): Conference Series https://jurnal.uns.ac.id/shes

p-ISSN 2620-9284

e-ISSN 2620-9292 


\section{PENDAHULUAN}

Masalah Pendidikan adalah investasi jangka panjang yang memperluas usaha dan membutuhkan dana yang cukup besar, hal ini diakui oleh semua orang atau suatu bangsa demi kelangsungan masa depannya. Demikian halnya dengan bangsa Indonesia menaruh harapan besar terhadap pendidik, dalam perkembangan masa depan bangsa ini, karena dari sanalah tunas muda harapan bangsa sebagi generasi penerus dibentuk.

Meski diakui bahwa pendidik adalah investasi besar jangka panjang yang harus ditata, disiapkan dan diberikan sarana maupun prasarananya. Dalam arti modal material yang cukup besar, tetapi sampai saat ini Indonesia masih terus berkutat pada problematika klasik dalam hal ini yaitu kualitas pendidikan. Permasalahan itu setelah dicoba untuk dicari permasalahannya adalah bagaikan sebuah mata rantai yang melingkar dan tidak tahu darimana mesti harus diawali.

Peserta dapat dikatakan memahami masalah apabila ia dapat menerjemahkan persoalan, menafsirkan dan menghubungkan permasalahan yang ada kemudian peserta didik dapat mencari penyelesaian kasus yang dihadapinya. Bertambah pengetahuannya, bisa memahami isi pelajaran, mampu menggunakan dan menerapkan ke situasi yang kongkrit, bisa menganalisis dan mengevaluasinya.

Peserta didik kelas II SDN Daleman Kidul 1 Kecamatan Pakis kabupaten Magelang yang berjumlah 15 anak. Kebanyakan para peserta didik adalah anak dari petani dan buruh tani sehingga orang tua mereka kurang memperhatikannya. Lingkungan kurang mendukung belajar anak, kebanyakan anak membantu orang tuanya, bermain sendiri, dan melihat TV pada malam hari, pekerjaan rumah siswa dikerjakan di sekolah sebelum sekolah masuk.

Selain itu masalah yang muncul dalam pembelajaran yaitu peserta didik kurang memahami penjelasan guru,peserta didik tidak mengerti kata-katayang diucapkan maupun yang ditulis guru. Hal ini mungkin karena penjelasan guru tidak disertai dengan media dan alat peraga yang sesuai. Penggunaan media pembelajaran masih minim dan kurang inovasi maka mengakibatkan minat belajar peserta didik menjadi berkurang.

Hasil pengamatan saya di dalam proses pembelajaran kelas 2 SDN Daleman Kidul 1 ,pada saat guru menjelaskan materi PPKn tentang aturan yang berlaku di dalam kehidupan sehari-hari. Peserta didik kurang merespon dan tidak termotivasi terhadap pembelajaran yang dilakukan oleh guru. Hal tersebut di karenakan proses pembelajaran dilaksanakan dengan menjelaskan teori dan ceramah tanpa melibatkan peserta didik dalam pembelajaran. Sehingga pemahaman peserta didik terhadap materi yang disampaikan berkurang dan pemahaman konsep terhadap materi juga tidak meraka terpenuhi

Faktor-faktor diatas jika tidak segera di atasi, maka akan menimmbulkan dampak negatif bagi peserta didik. Dampak yang ditimbulkan adalah peserta didik tidak memiliki keterampilan menyelesaikan masalah dalam pembelajaran. Dengan adanya hal tersebut menjadikan bahan pemikiran seorang guru untuk dapat menemukan model pembelajaran yang tepat dalam meningkatkan motivasi belajar peserta didik. Adapun peneliti dalam mengatasi masalah yang dihadapi peserta didik dalam pembelajaran adalah menggunakan media pembelajaran menggunakan PPT interaktif. Dengan menggunakan PPT interaktif diharapkan dapat meningkatkan motivasi belajar peserta didik dalam mengikuti pelajaran yang dilaksanakan guru.

Berdasarkan dari uraian diatas penulis melakukan penelitaian penerapan media pembelajaran yang tepat pada peserta didik. Oleh karena itu peneliti menyusun PTK dengan judul Peningkatan motivasi belajar peserta didik melalui media PPT intarktif pada materi PPKn tentang aturan dalam kehidupan sehari-hari kelas 2 SDN Daleman Kidul 1 Tahun pelajaran 2020/2021. 
Aturan adalah serangkaian ketentuan, petunjuk, patokan, atau perintah yang dibuat oleh manusia dengan tujuan untuk mengatur kehidupan manusia dalam sehariharinya agar tidak melakukan sikap brutal, ingin menang sendiri, dan lainnya. Secara bahasa, pengertian aturan adalah suatu pedoman agar manusia dapat hidup secara tertib dan teratur. Karena jika tidak ada peraturan, maka antar manusia dalam kehidupan bermasyarakat bisa bertindak sewenang-wenang, tanpa kendali dan sulit untuk diatur. Pada umumnya, aturan merupakan hasil keputusan bersama yang harus ditaati dan dilaksanakan dimana sikapnya mengikat. Aturan juga berkaitan dengan nilai norma dan adat yang berlaku di lingkungan bermasyarakat.Aturan biasanya bersifat mengikat secara lokal dimana hanya manusia dalam lingkungan tersebut saja yang memiliki kewajiban untuk menaati peraturan. Namun dalam makna yang lebih luas, istilah aturan tidak dapat didefinisikan sesederhana itu karena menyangkut perbedaan tujuan dan kebutuhan.

Motivasi belajar adalah keseluruhan daya penggerak dalam diri siswa yang menimbulkan kegiatan belajar, yang menjamin kelangsungan dari kegiatan belajar dan memberikan arah pada kegiatan belajar, sehingga tujuan yang dikehendaki oleh subyek belajar itu dapat tercapai (Sardiman, 1986: 75). Demikian dalam belajar, prestasi siswa akan lebih baik bila siswa memiliki dorongan motivasi orang tua untuk berhasil lebih besar dalam diri siswa itu. Sebab ada kecenderungan bahwa seseorang yang memiliki kecerdasan tinggi mungkin akan gagal berprestasi karena kurang adanya motivasi dari orang tua.

Microsft Power Point adalah sebuah program komputer untuk persentasi yang dikembangkan oleh Microsoft, Microsoft Office, meliputi Microsoft Power Point. Microsoft Word, Exel, Access dan beberapa program lainnya.

Microsoft power point adalah software perkantoran yang dirancang khusus untuk sebuah presentasi. Presentasi akan berjalan baik, lancar dengan hasil sesuai dengan yang anda harapkan, jika anda mengoptimalkan penggunaannya. Sebuah persentasi hadir tidak hanya berada dalam lingkup satu ruang. Canggihnya era jaringan komputer didukung sepenuhnya oleh Microsoft Power Point.

Persentasi merupakan metode pembelajaran dengan cara penyampaian melalui penjelasan informasi oleh penyampai materi ( dosen, guru, instruktur atau mahasiswa yang ditugasi untuk memaparkan sesuatu baik ide, gagasan ataupun penemuan). Presentasi merupakan proses komunikasi, yang terdiri atas penyampaian pesan (presenter), pesan itu sendiri yakni berbagai informasi yang ingin disampaikan, dan audiens atau penerima pesan yakni orang yang menerima penjelasan.

Tampilan Microsoft Power Point terdiri dari beberapa bagian antara lain: Title Bar adalah bagian Microsoft Power Point yang berisi nama file dan nama program yang sedang diaktifkan. Menu Bar adalah barisan menu-menu yang disajikan program power point yang didalamnya berisi perintah yang memiliki fungsi sendiri-sendiri seperti File, Edit, View,Insert, Tools, Slide Show, Window, Help. Didalam menu tersebut terdapat menu yang disebut submenu, masing-masing submenu telah dikelompokkan sesuai kriteria fungsinya. Seperti Save terdapat didalam File, Undo terdapat dalam Edit.

\section{METODE}

Penelitian ini adalah penelitian tindakan kelas (classroom action research) dengan menggunakan media PPT interaktif. Penelitian Tindakan kelas ini terdiri dari dari empat tahapan dasar yaitu perencanaan (planning) ,pelaksanaan (acting), pengamatan (observing) dan refleksi (reflecting). Analisis penelitian ini adalah analisis deskriptif kuantitatif kualitatif dimana dalam penelitian ini selain cara penyajian hasil berupa data maupun angka peneliti juga menggunakan diagram. Penelitian ini di laksanakan pada peserta didik pada kelas 2 SDN Daleman Kidul 1 Kecamatan Pakis 


\section{SHEs: Conference Series 3 (3) (2020) $1320-1328$}

Kabupaten magelang tahun pelajaran 2020/2021 selama tiga siklus secara luring. Siklus I dilaksanakan pada tanggal 16 November 2020. Siklus II dilaksanakan pada tanggal 23 November 2020. Siklus III dilaksanakan pada tanggal 4 Desember 2020. Teknik pengumpulan data yang dilakukan dengan observasi dan tes obesrvasi meliputi observasi sikap peserta didik keaktifan, motivasi belajar dan keterampilan dalam proses pembelajaran. Untuk hasil beajar menggunakan tes secara tertulis peserta didik mengerjakan soal evaluasi.

Deskripsi Hasil Siklus I

\section{HASIL DAN PEMBAHASAN}

Tabel Hasil Tes Kompetensi Peningkatan Penguasaan Materi PPKn tentang aturan dalam kehidupan sehari-hari pada hari kelas 2 SDN Dalemankidul I Kecamatan Pakis

Tabel 1. Siklus I

\begin{tabular}{clcccc}
\hline No & Kategori & $\begin{array}{c}\text { Rentang } \\
\text { Nilai }\end{array}$ & Frekuensi & Persentase & Rata-rata \\
\hline 1 & Sangat Baik & $81-100$ & 2 & 13.33 & \\
2 & Baik & $66-80$ & 11 & 73.33 & \\
3 & Cukup & $51-65$ & 2 & 13.33 & 77.33 \\
4 & Kurang & $0-50$ & & & \\
& & 15 & 100.00 & \\
\hline
\end{tabular}

Pada tabel diatas menunjukkan bahwa sebanyak 2 peserta didik dari 15 peserta didik atau sebesar $13.33 \%$., termasuk ke dalam kategori sangat baik, 11 peserta atau sebanyak $73.33 \%$, termasuk kedalam kategori baik, 2 peserta atau sebanyak 13.33 $\%$, termasuk ke dalam kategori cukup. Karena nilai yang diperoleh pada peserta pada siklus I yang mencapai ketuntasan belajar baru $73.33 \%$ atau 11 peserta didik dari 15 peserta didik.

Diagram hasil belajar siklus I Peningkatan Penguasaan Materi PPKn tentang aturan dalam kehidupan sehari-hari pada hari kelas 2 SDN Dalemankidul I Kecamatan Pakis

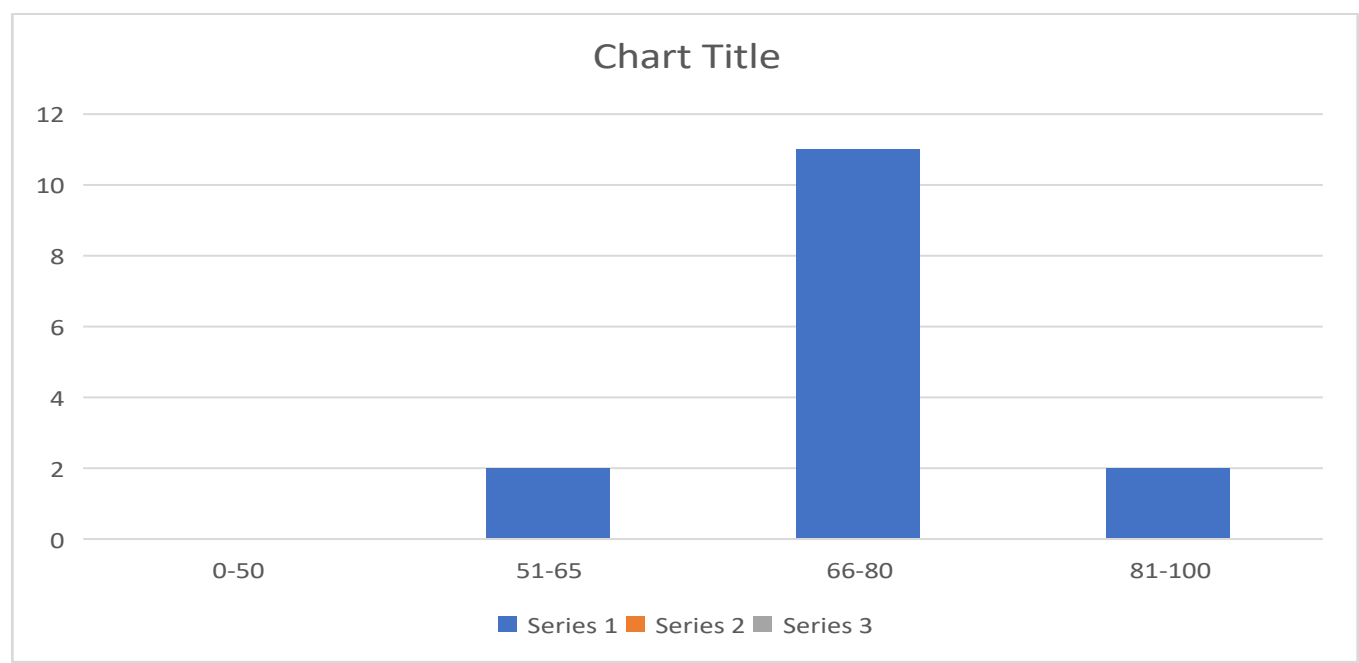

Grafik 1. Diagram hasil belajar siklus I 
Tabel rekapitulasi peningkatan motivasi belajar peserta didik untuk setiap siklus kegiatan pembelajaran

Tabel 2. peningkatan motivasi belajar peserta didik

\begin{tabular}{cccccc}
\hline No & Uraian & \multicolumn{2}{c}{$\begin{array}{c}\text { Peserta didik yang } \\
\text { belum termotivasi }\end{array}$} & \multicolumn{2}{c}{$\begin{array}{c}\text { Peserta didik yang } \\
\text { sudah termotifasi }\end{array}$} \\
\hline & & Frekuensi & $\%$ & Frekuensi & $\%$ \\
1 & Siklus 1 & 5 & 33,33 & 10 & 66,67 \\
\hline
\end{tabular}

Pada tabel diatas menunjukan bahwa sebanyak 5 peserta didik dari 15 peserta didik atau sebesar 33,33 \% termasuk dalam kategori peserta didik yang belum termotivasi dalam pembelajaran siklus 1 . Sedangkan 10 peserta didik dari 15 peserta didik atau 66,67 \% termasuk dalam kategori peserta didik yang sudah temotivasi. maka perlu diadakan tindakan perbaikan kelas siklus II untuk meningkatkan motivasi belajar peserta didik.

Deskripsi Hasil Siklus II

Tindakan siklus II ini dilakukan sebagai upaya untuk memperbaiki dan memecahkan masalah yang muncul pada siklus I. hasil tes siklus II yaitu berupa kompetensi motivasi belajar peserta didik melalui media PPT intarktif pada materi PPKn tentang aturan dalam kehidupan sehari-hari kelas 2 dilakukan siklus I. hasil tes siklus II ini bertujuan untuk mengetahui kondisi kompetensi peningkatan motivasi belajar peserta didik melalui media PPT intarktif pada materi PPKn tentang aturan dalam kehidupan sehari-hari kelas 2 setelah siklus I. jumlah siswa yang mengikuti siklus II ini berjumlah 15 siswa. Hasil tes siklus II dapat dilihat pada tabel berikut ini.

Tabel Hasil Tes Kompetensi Peningkatan motivasi belajar peserta didik melalui media PPT intarktif pada materi PPKn tentang aturan dalam kehidupan sehari-hari kelas 2.

Tabel 2. Siklus II

\begin{tabular}{llcccc}
\hline No & Kategori & $\begin{array}{c}\text { Rentang } \\
\text { Nilai }\end{array}$ & Frekuensi & Persentase & Rata-rata \\
\hline 1 & Sangat Baik & $81-100$ & 9 & $60 \%$ & \\
2 & Baik & $66-80$ & 6 & $40 \%$ & \\
3 & Cukup & $51-65$ & & & 88 \\
4 & Kurang & $0-50$ & & & \\
& & 15 & $100 \%$ & \\
\hline
\end{tabular}

Berdasarkan data diatas perolehan hasil belajar siswa kompetensi peningkatan motivasi belajar peserta didik melalui media PPT intarktif pada materi PPKn tentang aturan dalam kehidupan sehari-hari kelas 2 SDN Dalemankidul I termasuk dalam kategori sangat baik dari 15 siswa sebesar $60 \%$, kategori baik, $40 \%$ kategori cukup, dan sebesar $0 \%$. Berarti pada perbaikan pembelajaran pada siklus II ini berada pada kategori baik.

Diagram hasil belajar siklus II Peningkatan Penguasaan Materi PPKn tentang aturan dalam kehidupan sehari-hari pada hari kelas 2 SDN Dalemankidul I

Kecamatan Pakis 
SHEs: Conference Series 3 (3) (2020) $1320-1328$

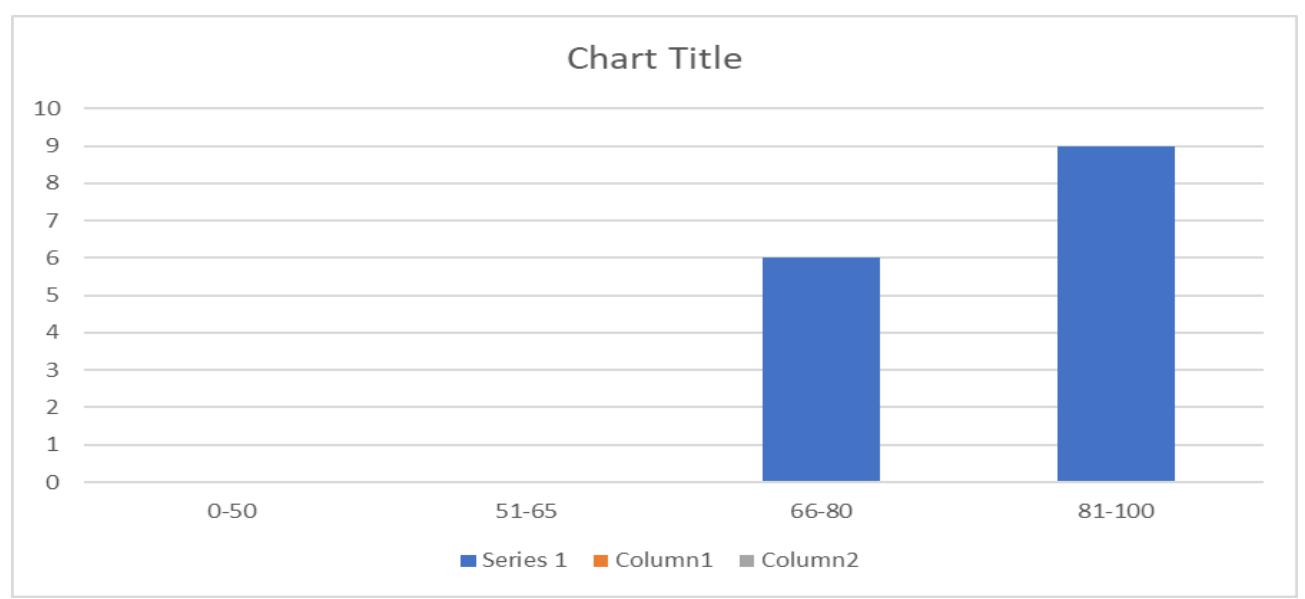

Grafik 2. Diagram hasil belajar siklus II

Tabel rekapitulasi peningkatan motivasi belajar peserta didik untuk setiap siklus kegiatan pembelajaran

Tabel 2. Rekapitulasi peningkatan motivasi belajar peserta didik

\begin{tabular}{cccccc}
\hline \multirow{2}{*}{ No } & Uraian & \multicolumn{2}{c}{$\begin{array}{c}\text { Peserta didik yang } \\
\text { belum termotivasi }\end{array}$} & \multicolumn{2}{c}{$\begin{array}{c}\text { Peserta didik yang } \\
\text { sudah termotifasi }\end{array}$} \\
& & Frekuensi & $\%$ & Frekuensi & $\%$ \\
\hline 1 & Siklus 2 & 2 & 13,33 & 13 & 86,67 \\
\hline
\end{tabular}

Berdasarkan tabel di atas menunjukan bahwa sebanyak 2 peserta didik dari 15 peserta didik atau sebesar 13,33\% termasuk dalam kategori peserta didik yang belum termotivasi dalam pembelajaran siklus II. Sedangkan 13 peserta didik dari 15 peserta didik atau 86,67 \% termasuk dalam kategori peserta didik yang sudah temotivasi. maka perlu diadakan tindakan perbaikan kelas siklus II untuk meningkatkan motivasi belajar peserta didik.

Deskripsi Hasil Siklus III

Tindakan siklus III ini dilakukan sebagai upaya untuk memperbaiki dan memecahkan masalah yang muncul pada siklus II. hasil tes siklus III yaitu berupa kompetensi motivasi belajar peserta didik melalui media PPT intarktif pada materi PPKn tentang aturan dalam kehidupan sehari-hari kelas 2 dilakukan siklus III. hasil tes siklus III ini bertujuan untuk mengetahui kondisi kompetensi peningkatan motivasi belajar peserta didik melalui media PPT intarktif pada materi PPKn tentang aturan dalam kehidupan sehari-hari kelas 2 setelah siklus III. jumlah peserta didik yang mengikuti pembelajaran di siklus III ini berjumlah 15 peserta didik. Hasil tes siklus III dapat dilihat pada tabel berikut ini.

Tabel Hasil Tes Kompetensi Peningkatan motivasi belajar peserta didik melalui media PPT intarktif pada materi PPKn tentang aturan dalam kehidupan sehari-hari kelas 2. 
SHEs: Conference Series 3 (3) (2020) $1320-1328$

Tabel 3. Siklus III

\begin{tabular}{cccccc}
\hline No & Kategori & $\begin{array}{c}\text { Rentang } \\
\text { Nilai }\end{array}$ & Frekuensi & Persentase & $\begin{array}{c}\text { Rata- } \\
\text { rata }\end{array}$ \\
\hline 1 & $\begin{array}{c}\text { Sangat } \\
\text { Baik }\end{array}$ & $81-100$ & 10 & $66,66 \%$ & \\
2 & Baik & $66-80$ & 5 & $33,33 \%$ & \\
3 & Cukup & $51-65$ & & & 92 \\
4 & Kurang & $0-50$ & & & \\
\multicolumn{2}{c}{ Jumlah } & 15 & $100 \%$ & \\
\hline
\end{tabular}

Berdasarkan data diatas perolehan hasil belajar siswa kompetensi peningkatan motivasi belajar peserta didik melalui media PPT intarktif pada materi PPKn tentang aturan dalam kehidupan sehari-hari kelas 2 SDN Dalemankidul I termasuk dalam kategori sangat baik dari 15 siswa sebesar 10 peserta didik atau 66,66 \% dan kategori baik 5 peserta didik dari 15 atau 33,33\%. Berarti pada perbaikan pembelajaran pada siklus III ini rata -rata belajar peserta didik 92.

Diagram hasil belajar siklus III Peningkatan Penguasaan Materi PPKn tentang aturan dalam kehidupan sehari-hari pada hari kelas 2 SDN Dalemankidul I Kecamatan Pakis

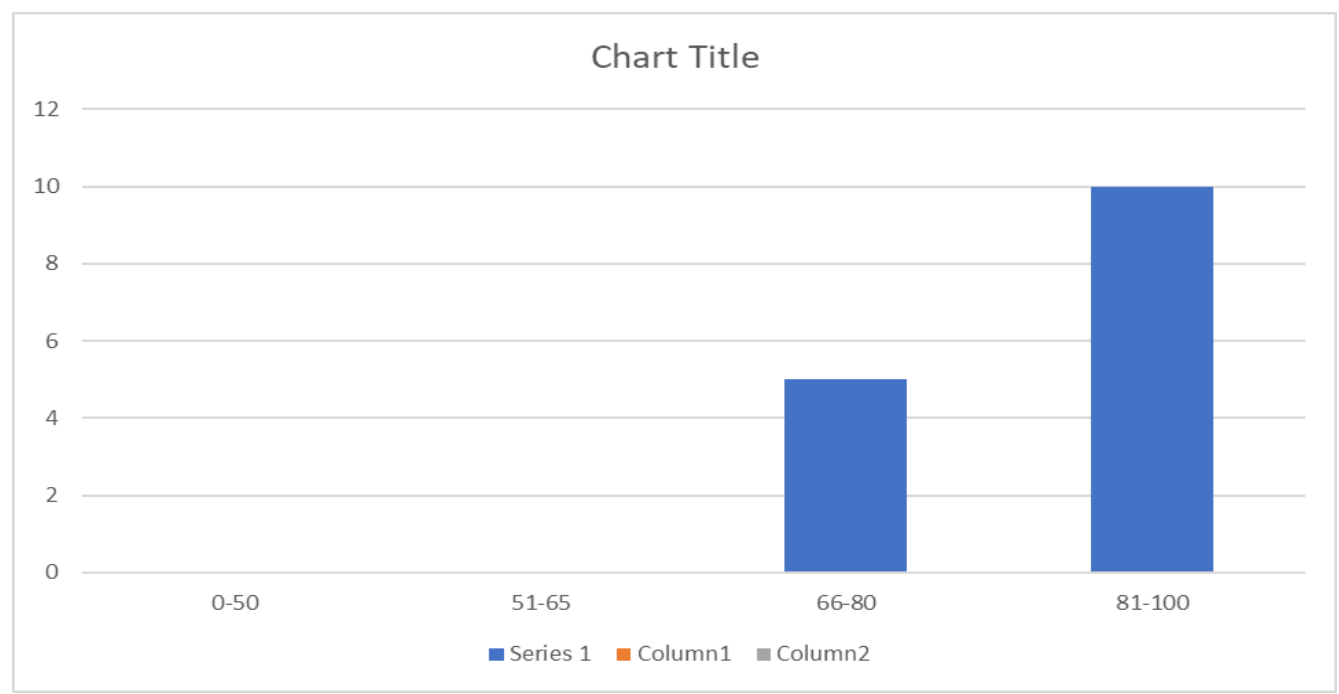

Grafik 3. Diagram hasil belajar siklus III

Tabel rekapitulasi peningkatan motivasi belajar peserta didik untuk setiap siklus kegiatan pembelajaran

Tabel 4. Rekapitulasi peningkatan motivasi belajar peserta didik

\begin{tabular}{cccccc}
\hline No & Uraian & \multicolumn{2}{c}{$\begin{array}{c}\text { Peserta didik yang belum } \\
\text { termotivasi }\end{array}$} & \multicolumn{2}{c}{$\begin{array}{c}\text { Peserta didik yang sudah } \\
\text { termotifasi }\end{array}$} \\
& & Frekuensi & $\%$ & Frekuensi & $\%$ \\
\hline 1 & Siklus 3 & 1 & 7,14 & 14 & 93,33 \\
\hline
\end{tabular}


Berdasarkan tabel di atas menunjukan bahwa sebanyak 1 peserta didik dari 15 peserta didik atau sebesar $7,14 \%$ termasuk dalam kategori peserta didik yang belum termotivasi dalam pembelajaran siklus III. Sedangkan 14 peserta didik dari 15 peserta didik atau 93,33\% termasuk dalam kategori peserta didik yang sudah temotivasi. Maka tindakan perbaikan kelas siklus III untuk meningkatkan motivasi belajar peserta didik dengan menggunakan media PPT interaktif sudah berhasil untuk meningkatkan motivasi belajar peserta didik pada materi PPKn tentang aturan dalam kehidupan sehari-hari kelas 2 SDN Dalemankidul I.

Peningkatan motivasi belajar peserta didik, baik hasil maupun proses pembelajaran setelah menggunakan media PPT interaktif. Hasil belajar siswa ini dianalisis dan diperoleh dari kemampuan siswa pada kompetensi peningkatan motivasi belajar peserta didik melalui media PPT intarktif pada materi PPKn tentang aturan dalam kehidupan sehari-hari kelas 2 SDN Dalemankidul I. Hal ini ditunjukkan dengan nilai rata-rata yang diperoleh siswa pada siklus I sebesar 77.33. Nilai rata-rata kelas yang diperoleh siswa dari hasil tes tersebut dalam kategori tuntas. Peserta didik yang sudah termotivasi pada siklus 1 ini adalah baru 66,67 \% dari jumlah peserta didik 15 . Setelah dilaksanakan pembelajaran melalui media PPT interktif siklus II dengan kompetensi yang sama, ternyata kesulitan peserta didik yang belum termotivasi dapat diatasi . Hasil belajar siswa pada siklus II mengalami peningkatan perolehan nilai ratarata kelas sebesar 88 Nilai rata-rata kelas pada siklus II tersebut dalam kategori tuntas. Setelah dilaksanakan perbaikan pada siklus II hasil belajar siswa meningkat. Keberhasilan belajar siswa dapat di lihat dari perolehan rata-rata kelas meningkat menjadi $60 \%$ dan dalam kategori sangat baik , $40 \%$ dalam kategori baik. Peserta didik yang termotimasi belajarnya adalah $86,67 \%$ atau 13 peserta didik dari 15 . Sedangkan peserta didik yang belum termotivasi belajarnya adalah 13,33\% atau sebanyak 2 peserta didik dari 15. Hasil belajar peserta didik pada siklus III menunjukkan peningkatan, keberhasilan belajar peserta didik dapat dilihat dari rata-tata kelas mendapat 92. Peserta didik 1 dari 15 peserta didik atau sebesar 7,14\% termasuk dalam kategori peserta didik yang belum termotivasi dalam pembelajaran siklus III. Sedangkan 14 peserta didik dari 15 peserta didik atau 93,33\% termasuk dalam kategori peserta didik yang sudah temotivasi

Peningkatan perbaikan pembelajaran dari siklus I dan siklus II dapat dilihat pada tabel Berikut:

Tabel 5. Peningkatan perbaikan pembelajaran dari siklus I dan siklus II

\begin{tabular}{cccccc}
\hline \multirow{2}{*}{ SIKLUS } & \multirow{2}{*}{$\begin{array}{c}\text { RATA-RATA } \\
\text { NILAI }\end{array}$} & SANGAT BAIK & BAIK & CUKUP & KURANG \\
\hline I & 77.33 & $13.33 \%$ & $73.33 \%$ & $13.33 \%$ & $0 \%$ \\
II & 88 & $60 \%$ & $40 \%$ & $0 \%$ & $0 \%$ \\
III & 92 & $66,66 \%$ & $33,33 \%$ & $0 \%$ & $0 \%$ \\
\hline
\end{tabular}

Tabel rekapitulasi peningkatan motivasi belajar peserta didik untuk setiap siklus kegiatan pembelajaran

Tabel 6. Rekapitulasi peningkatan motivasi belajar peserta didik untuk setiap siklus

\begin{tabular}{cccccc}
\hline \multirow{2}{*}{ No } & \multirow{2}{*}{ Uraian } & \multicolumn{2}{c}{$\begin{array}{c}\text { Peserta didik yang belum } \\
\text { termotivasi }\end{array}$} & \multicolumn{2}{c}{$\begin{array}{c}\text { Peserta didik yang } \\
\text { sudah termotifasi }\end{array}$} \\
& & Frekuensi & $\%$ & Frekuensi & $\%$ \\
\hline 1 & Siklus 1 & 5 & 33,33 & 10 & 66,67 \\
2 & Siklus 2 & 2 & 13,33 & 13 & 86,67 \\
2 & Siklus 3 & 1 & 7,14 & 14 & 93,33 \\
\hline
\end{tabular}




\section{SIMPULAN}

Peningkatan motivasi belajar peserta didik melalui media PPT intarktif pada materi PPKn tentang aturan dalam kehidupan sehari-hari kelas 2 SDN Dalemankidul I kecamatan Pakis, dengan mengggunakan media PPT interaktif dapat meningkatkan motivasi belajar peserta didik. Hal ini dibuktikan dari hasil penelitian menunjuukan bahwa dari perbaikan pembelajaran setiap siklus mengalami peningkatan pada peserta didik yang termotivasi belajarnya. pada siklus 1peserta didik yang sudah termotivasi belajarnya dari 15 peserta didik mencapai 66,67\%. Pada siklus ke II mengalami peningkatan $86,67 \%$. Adapun pada siklus III peserta didik yang sudah termotivasi belajarnya mencapai $93,33 \%$.

Melalui penggunaan media PPT interaktif dapat merangsang keaktifan peserta didik dalam pembelajaran. Pembelajaran juga terlihat lebih menarik dan menyenangkan, aktifitas belajar peserta didik yang awalnya terihat malas mengikuti pelajaran menjadi bersemangat mengikuti proses pembelajaran.

\section{DAFTAR PUSTAKA}

Marisa, dkk. 2012. komputer Media Pembelajaran

Maxmanro internet pengertian aturan dan jenis-jenis aturan

Muchlisin Riyadi. Kajian pustaka. Com

Priyitno, Elida. 1989. Motivasi Dalam Belajar. Jakarta: P2LPTK

Sardiman, A,M. 1990. Interaksi dan Motivasi Belajar Mengajar. Jakarta: Rajawali.

S Rizal, B Walidain - JURNAL ILMIAH DIDAKTIKA: Media ..., 2019

- jurnal.ar-raniry.ac.id 